
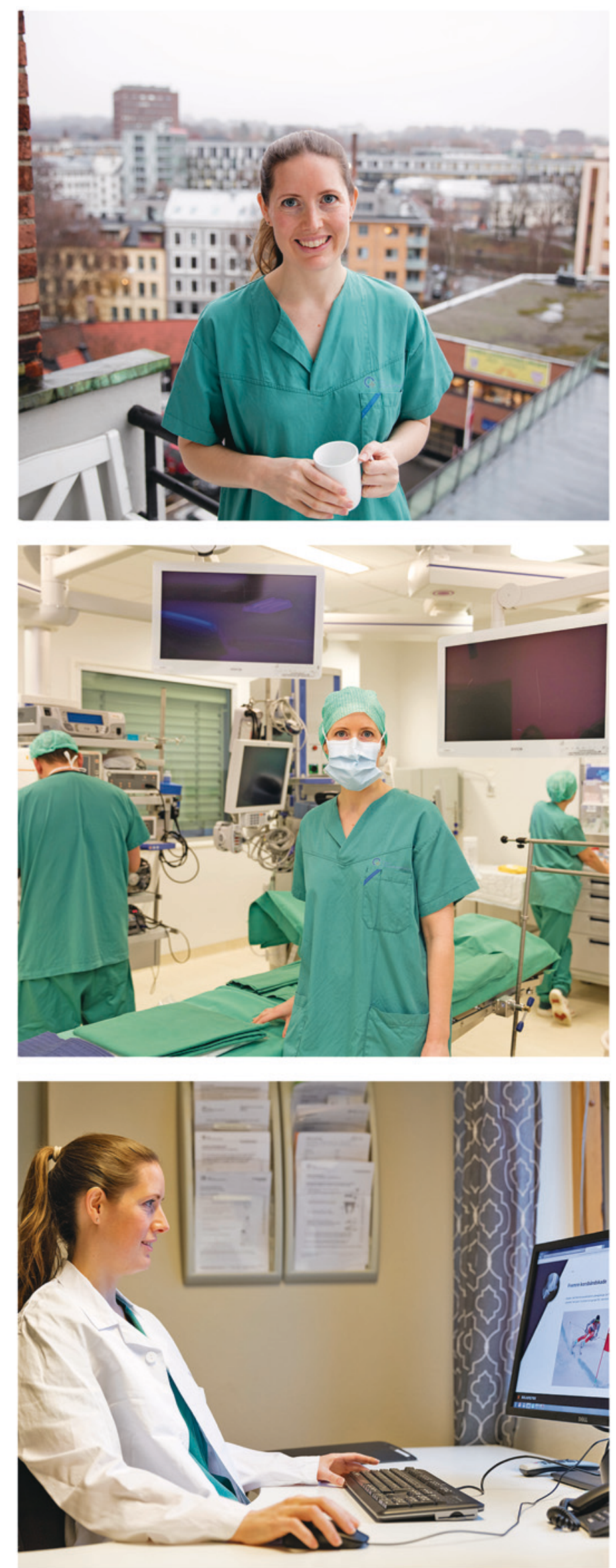

Foto: Christian Tunge

\section{Kirurgi versus trening - ortopedi anno 2016}

Guri Ranum Ekås er spesialist i ortopedi, fellow ved artroskopiseksjonen ved Oslo universitetssykehus, UIlevål, ph.d.-kandidat ved Oslo Sports Trauma Research Centre og lege for landslaget i skihopp. Klinisk og i forskningen er det kneskader hun er opptatt av.

\section{Kan du fortelle om noe viktig som skjer i faget ditt for tiden?}

Ortopedien er i endring. Det gjøres stadig fremskritt innen bioteknologi, ortopediske implantater, kirurgiteknisk og diagnostisk utstyr. Samtidig står kliniske tradisjoner sterkt $\mathrm{i}$ vårt fag. Bildediagnostikk er et viktig hjelpemiddel, men klinisk undersøkelse og funksjonsvurdering er avgjørende for å kunne stille operasjonsindikasjon. Vil pasienten ha utbytte av kirurgisk behandling? Kan inngrepet foregå innen trygge medisinske rammer? Svarene på disse spørsmålene og premissene som ligger til grunn for å stille operasjonsindikasjon endres i takt med kirurgiske fremskritt og ny kunnskap. Innen artroskopisk knekirurgi har vi nå flere muligheter enn noen gang, men samtidig ser vi en dreining mot mer konservativ behandling av enkelte grupper. Ikke fordi man ikke er villig til å gi disse gruppene den beste behandling, men fordi ny kunnskap tyder på at kirurgi ikke er det beste.

\section{Kan du anbefale en ny og interessant artikkel?}

Studier viser at det ikke er grunnlag for å anbefale meniskreseksjon hos voksne med degenerative meniskskader. Blant disse er Nina Kise og medarbeideres studie, publisert i $B M J(1)$. Det kliniske skjønn må likevel holdes i hevd - det er ikke slik at voksne med degenerative menisker aldri skal opereres. Er kneet låst eller det er låsningsfenomener, kan det likevel være operasjonsindikasjon. Vi legger i økende grad vekt på betydningen av treningsterapi ved korsbåndsskade i kneet. Korsbåndspasienter uten operasjonskrevende tilleggsskade som ikke bedriver knekrevende idrett eller arbeid, kan behandles konservativt dersom de evner å oppnå knestabilitet ved trening alene. Vi jobber nå for å forbedre det nasjonale korsbåndsregisteret slik at også de ikke-opererte pasientene kan registreres og følges over tid. Dette vil øke kunnskapen om det ikke-operative behandlingsalternativet og på sikt heve kvaliteten på pasientbehandlingen.

\section{Hva er ditt favoritthjelpemiddel på jobb?}

For idrettsskader er forebygging beste medisin! Et nyttig verktøy for å promotere skadeforebyggende trening er nettsiden og appen Skadefri (2). Her kan man lære ulike treningsøvelser med skadeforebyggende effekt.

\section{Anbefalt litteratur}

1. Kise NJ, Risberg MA, Stensrud S et al. Exercise therapy versus arthroscopic partial meniscectomy for degenerative meniscal tear in middle aged patients: randomised controlled trial with two year follow-up. BMJ 2016; 354: i3740.

2. Skadefri - Best uten skader. http://www.skadefri.no/(20.9.2016).

Har du tips til personer vi kan intervjue? Ta kontakt med lisa.dahlbak.jacobsen@tidsskriftet.no 